\title{
A variação linguística em traduções de alta literatura e de best-sellers de ficção popular
}

\section{Linguistic variation in translations of "highbrow literature" and of best-selling popular fiction}

\author{
Lauro Maia Amorim
}

Resumo: Embora o estudo da variação linguística em traduções literárias tenha estimulado um debate notável nos Estudos da Tradução nas últimas décadas, pouca reflexão tem sido desenvolvida em torno da (in)existência de uma relação entre o emprego de marcas de oralidade e traduções de obras da chamada alta literatura e de best-sellers de ficção. Seria possível observar algum contraste relevante, quanto às marcas de oralidade, entre obras de ficção às quais se atribuem, em princípio, objetivos mercadológicos distintos? Para responder a essa questão, realizou-se uma pesquisa comparativa com o objetivo de quantificar as ocorrências de marcas de oralidade, tais como as delineadas por Britto (2012), em uma tradução associada à alta literatura (Indignação, de Philip Roth), e em outra caracterizada como um típico best-seller de entretenimento ( $O$ Manipulador, de John Grisham).

Palavras-chave: Sociolinguística aplicada à tradução; Marcas de oralidade; Alta literatura; Best-sellers de ficção.

Abstract: Although the study of linguistic variation in literary translations has stimulated considerable debate in Translation Studies in the last few decades, very little discussion has been developed on the (in)existence of a relationship between the use of written orality and translations of the so-called highbrow literature and that of bestselling fiction. Is there any relevant contrast, in terms of "written orality" occurrence, among works of fiction to which, in principle, different marketing purposes are ascribed? To answer this question, a comparative research was carried out so as to quantify written orality features, such as those outlined by Britto (2012),

\footnotetext{
* Departamento de Estudos Linguísticos e Literários. Universidade Estadual Paulista (UNESP), campus de São José do Rio Preto. lauro.maia@unesp.br
} 
in a translation of a highbrow novel (Indignation, by Philip Roth), and of a bestselling novel (The Racketeer, by John Grisham).

Keywords: Sociolinguistics applied to translation; Written orality; "Highbrow literature"; Best-selling fiction.

\section{Introdução: marcas de oralidade em traduções literárias e a linguagem urbana}

\section{comum}

Contribuições significativas sobre o estudo da representação da variação linguística em textos literários têm sido feitas por pesquisadores cujo interesse de pesquisa, a exemplo de Preti (1994, 2004) e Azevedo (2003), entre outros, recai, primordialmente, sobre a análise de textos da literatura brasileira. Embora, no Brasil, seja notável o número crescente de estudos dedicados à observação da representação da oralidade em traduções literárias nas últimas décadas, não se pode concluir, com isso, que a variação sociolinguística esteja amplamente representada na maioria das traduções literárias produzidas no mercado editorial brasileiro atual, até porque, salvo engano, não parece haver pesquisas que atestem empiricamente essa informação.

Se, por um lado, a busca pela representação dessa variação, na escrita, possa atender tanto à necessidade autoral ou do tradutor de demarcar diferenças sociais e estilísticas entre personagens, quanto à possibilidade de tornar diálogos mais verossímeis, por outro, há que considerar os próprios limites impostos à representação plena das características da língua falada, o que não tem impedido que marcas de oralidade se façam presentes na prática de tradutores literários brasileiros.

É o caso, por exemplo, de Paulo Henriques Britto (2012), tradutor com vasta experiência e que tem aplicado, em sua própria prática, marcas de oralidade como um recurso para formular diálogos ficcionais mais próximos da 
realidade falada. As marcas de oralidade serviriam ao propósito de criar um efeito de verossimilhança, ou seja, a ilusão de que o diálogo literário seria real, justamente porque, no caso de vários exemplos oferecidos por Britto (2012), essas marcas são representações de formas linguísticas que, embora materializadas na escrita, são mais próximas da modalidade oral da língua portuguesa.

Em sua reflexão sobre a prática tradutória envolvendo marcas de oralidade, Britto (2012:92) considera que haveria três tipos de marcas: as fonéticas, as lexicais (ou léxico-frasais) e as morfossintáticas. As primeiras seriam aquelas com as quais se buscaria representar, na escrita, determinadas reduções fonéticas, como no caso de "pra" ou "né?". Britto (2012) salienta que as marcas fonéticas (como no caso de "cê") teriam o emprego mais limitado, justamente porque o leitor tenderia a identificá-las como sendo não padrão. Embora a forma reduzida "cê" seja efetivamente falada em várias regiões do Brasil, por diferentes classes sociais, e não seja vista de maneira estigmatizada, a percepção mais conservadora que se tem da modalidade escrita confere a esses usos o estatuto de incorreção.

As marcas lexicais ou léxico-frasais seriam palavras utilizadas com frequência no contexto oral, como gírias comuns ("Aquela festa tá animal”; "pagou o maior mico"), palavras de baixo calão ("puta que pariu!") e outras formas de coloquialismo (“e aí, beleza?”; “bacana.”). ${ }^{1}$

As marcas morfossintáticas, segundo Britto (2012), seriam mais produtivas por representarem, na escrita, o seu uso generalizado no plano oral em grande parte do país e permitirem um efeito desejável de verossimilhança em diálogos. É o caso do emprego do sistema pronominal misto, em que "te" é utilizado ao lado de "você", como em "Você lavou aquela faca que te dei?". Outro caso é o uso de pronome sujeito lexical na função de objeto verbal, como no exemplo "Você viu ele?". Destacam-se também o uso redundante do pronome sujeito ("Eu comprei essa casa"); próclise em vez de ênclise (“Minha irmã me deu um presente”); uso de artigo

\footnotetext{
1 Embora essas marcas de oralidade (associadas a gírias e coloquialismos) tenham sido pesquisadas, elas não foram incluídas neste trabalho porque não chegam a se destacar nas obras analisadas.
} 
definido antes de nome próprio ("Eu falei com o Carlos ontem"); uso do substantivo singular sem artigo em referência genérica ("Brasileiro não tem jeito mesmo"); emprego do singular para se referir a um par ("Vai lavar a mão, menino!"); dupla negativa ("Não vi ninguém, não"); uso de "que” após pronome interrogativo e conjunção integrante ("Quando é que ele vem?"/“0 quê que há com você?"/"O que é que há com você?"); uso não canônico de preposições, como substituir a preposição "a" por "em", no caso do verbo chegar ("Chegou em São Paulo ontem"), ou por "para", no caso do verbo ir ("Foi pra Bahia passear"); orações adjetivas com o uso de pronome lembrete (em vez da forma padrão, "É o rapaz cujo irmão foi atropelado", teríamos: “É o rapaz que o irmão dele foi atropelado") ou, ainda, com a variante cortadora, como em "É o rapaz que o irmão Ø foi atropelado"; emprego de formas verbais analíticas em substituição a formas sintéticas ("Eu vou fazer 0 possível”, em vez de "Eu farei o possível”; "João já tinha falado com Pedro", em vez de "João falara com Pedro"), entre outros exemplos.

Em vista do que foi exposto acima, pode-se fazer a distinção entre dois aspectos: variantes linguísticas não padrão consideradas estigmatizadas (como "A gente fomo pra casa") e variantes linguísticas que, embora do ponto de vista de certos compêndios gramaticais normativos sejam tidas como não padrão, não chegam a ser, de fato, estigmatizadas, na prática linguística diária, como vários dos exemplos apresentados acima por Britto (2012). ${ }^{2}$ Esses exemplos apontam, na realidade, para certa proximidade/intersecção entre a

\footnotetext{
${ }^{2}$ Ressalta-se que essas marcas de oralidade estão próximas da representação oral diafásica (que envolve menor monitoração da fala pelo falante, sendo mais caracterizadas pelo registro informal), do que das representações orais mais típicas da variação diatópica (geográfica), e da variação diastrática (social), especialmente a que se relacione, por exemplo, com o menor grau de escolaridade. A variação linguística, como demonstra Faraco (2008:44), é fruto do entrecruzamento de três continua: "[variedades] do polo urbano (no eixo rural-urbano) com o polo do letramento (no eixo oralidade-letramento) e [do] eixo da monitoração estilística, [incluindo variedades de] diferentes estilos, desde os menos até os mais monitorados". Assim, as variedades aqui descritas são mais próximas do universo urbano e da oralidade, sendo também menos monitoradas. Destaca-se, porém, que do ponto de vista diastrático, essas marcas de oralidade, quando utilizadas, não chegam a sugerir que os personagens que as produziram tenham um grau reduzido de escolaridade (ou que sejam de classes sociais mais baixas). Assim, ainda que essas formas sejam mais próximas da oralidade, elas não excluem ou se opõem à dimensão "letramento" que compõe o eixo oralidade-letramento da variação linguística.
} 
chamada linguagem urbana comum e a norma culta falada (e escrita). ${ }^{3}$ Ao discutir os estudos realizados sobre as gravações do Projeto NURC (envolvendo a análise da norma urbana culta), ${ }^{4}$ Faraco (2009) afirma o seguinte:

A realidade [...] desconcertou o imaginário [dos pesquisadores que supunham que os falantes cultos, em situações de fala monitorada, seguiriam fielmente as regras ditadas pelos compêndios]: a norma culta brasileira falada se identifica, na maioria das vezes, com a linguagem urbana comum, ou seja, com a fala dos falantes que estão fora do grupo dos chamados (tecnicamente) de cultos (cf. Preti, 1997, p. 18) e não propriamente com as prescrições da tradição gramatical conservadora. (FARACO, 2009:46)

Preti (1997) fornece mais detalhes acerca dessa importante conclusão:

Em síntese, o que o corpus do Projeto NURC/SP tem nos mostrado (e isso já na década de 1970) é que os falantes cultos, por influência das transformações sociais contemporâneas que aludimos antes (fundamentalmente, o processo de democratização da cultura urbana), o uso linguístico comum (principalmente a ação da norma empregada pela mídia) além de problemas tipicamente interacionais, utilizam praticamente o mesmo discurso dos falantes urbanos comuns, de escolaridade média, até em gravações conscientes e, portanto, de menor espontaneidade (1997:26).

Pode-se depreender que o que Britto (2012) denomina marcas de oralidade (como as exemplificadas acima) e que advoga como meios alternativos de tradução para a construção de diálogos menos artificiais e mais verossímeis (e que, em tese, não necessariamente atrairiam rejeição por parte do leitor), são formas linguísticas que não chegam a ser, de fato, estigmatizadas nos intercâmbios linguísticos orais, justamente porque, de certa forma, são produzidas inclusive no próprio discurso dos falantes letrados. $^{5}$

\footnotetext{
${ }^{3}$ Marcos Bagno $(2001,2009)$ apresenta várias ocorrências linguísticas que, embora sejam desabonadas por muitos compêndios gramaticais, são amplamente empregadas nos mais variados tipos de texto.

4 "O Projeto de Estudo da Norma Linguística Urbana Culta no Brasil (Projeto NURC) teve início em 1969 e vem se desenvolvendo em cinco cidades brasileiras - Recife, Salvador, Rio de Janeiro, São Paulo e Porto Alegre. Objetiva descrever os padrões reais de uso na comunicação oral adotados pelo estrato social constituído de falantes com escolaridade de nível superior." (fonte: https://twiki.ufba.br/twiki/bin/view/Alib/AlibNurc).

${ }^{5}$ Faraco (2009: 46) afirma que "isso não significa que os falantes ditos cultos não usem estruturas preconizadas pela tradição gramatical conservadora em sua fala monitorada. Algumas dessas ocorrem na norma culta falada, mas, pelo que os dados indicam, sempre variavelmente com suas correspondentes não 'autorizadas' (e até mesmo 'condenadas') pela
} 
Vale ressaltar, também, que as marcas de oralidade que Britto (2012) advoga para a elaboração de diálogos literários mais verossímeis são, em grande medida, formas correspondentes a construções linguísticas que, em um texto de partida escrito em inglês, não refletem usos necessariamente considerados estigmatizados nessa língua, isso porque, segundo o autor, a distância entre o registro escrito e o falado no inglês, especialmente na tradição literária anglófona, seria menor do que aquele que se observa, tradicionalmente, entre o registro oral e o escrito na língua portuguesa (BRITTO, 2012: 83). Em outras palavras, não seria equivocada a percepção de que textos literários em língua inglesa refletiriam certos usos linguísticos muito mais próximos da oralidade sem necessariamente suscitar reações judicativas dos falantes de língua inglesa, ou, pelo menos, não mais do que aquelas possivelmente geradas com a leitura de textos literários escritos em português com certas marcas de oralidade.

Embora, salvo engano, não disponhamos, até o momento, de pesquisas que avaliem, experimentalmente, a reação concreta (positiva, negativa ou indiferente) dos leitores finais à representação da variação linguística em traduções literárias, pode-se observar "indiretamente" a avaliação pressuposta, seja ela positiva ou não, por parte do tradutor que, amparado pela editora, emprega formas linguísticas mais ou menos próximas da oralidade, o que pode ser um indicativo do que o tradutor e a editora julgam, na condição de leitores prévios de uma obra literária (a ser) publicada, o que seria linguisticamente aceitável na divulgação dessa obra. Ainda que não possa ser tomada como uma representação direta do julgamento do leitor final da tradução, a opção linguística definitiva, (supostamente) feita pelo tradutor, e mantida pela editora na publicação, parece sugerir, minimamente, a necessidade de se corresponder a uma expectativa de valoração imaginada e atribuída ao provável leitor final da obra publicada.

Se as marcas de oralidade, como as que foram delineadas por Britto (2012), representam, em diálogos escritos, formas linguísticas muito próximas da linguagem comum urbana efetivamente produzida até por falantes

tradição gramatical mais conservadora, que, no entanto, são normais na linguagem urbana comum". 
brasileiros de escolaridade superior, poderíamos concluir que não há uma razão, minimamente fundamentada na realidade linguística, para que essas marcas não possam ser plenamente empregadas em diálogos de traduções literárias. No entanto, sabe-se que há uma tradição gramatical conservadora (difundida em compêndios gramaticais, presente no discurso de gramáticos, jornalistas, professores e escritores, e nas mais variadas mídias e meios de comunicação) que estabelece a norma padrão como uma única forma linguística ideal a ser seguida, primordialmente fundada na tradição literária do século XIX, de influência lusitana, e pouco representativa das formas linguísticas reais que a grande maioria dos falantes e escreventes brasileiros letrados produzem efetivamente em suas práticas comunicativas. Essas práticas são muito mais condizentes com a chamada "norma culta" que, diferentemente da "norma padrão" idealizada, é mais "porosa" e permeável às influências advindas da oralidade, refletindo, de fato, as mudanças linguísticas em implementação ou já implementadas na língua portuguesa falada no Brasil. ${ }^{6}$

Como demonstra Bagno (2012), apesar da existência de uma realidade discursiva normativa, pautada nos valores idealizados da norma padrão, ela não é suficiente para impedir que, em obras traduzidas, haja um hibridismo ou mescla de normas, com a coocorrência de formas linguísticas alinhadas à norma padrão e outras mais próximas da norma culta, o que revela a dificuldade com que se deparam tradutores e revisores em empregar plenamente formas linguísticas consagradas pelo uso (da "norma culta"), mas, também, em seguir, estritamente, as regras gramaticais pouco intuitivas que são impostas pelo discurso normativo tradicional (da "norma padrão").

A questão que se coloca, neste trabalho, é se a existência de marcas de oralidade ou, talvez, a maior ou menor ocorrência dessas marcas em um texto literário traduzido (o que indica o seu grau de hibridismo), especialmente no que diz respeito aos diálogos ficcionais, corresponderia simplesmente a um condicionamento gerado pela maior ou menor aderência (do tradutor e da editora) aos ditames da norma padrão tradicional, ou se essa maior ou menor

\footnotetext{
${ }^{6}$ Para uma discussão mais detalhada acerca das diferenças entre norma culta e norma padrão, ver Faraco (2008), Bagno (2012) e Luchesi (2015).
} 
aderência poderia ser condicionada também por outros fatores. Esse questionamento surgiu justamente com a leitura do trabalho de Britto (2012), no qual, como se sabe, o autor/tradutor advoga o uso de marcas de oralidade para a elaboração de diálogos mais verossímeis em traduções literárias. Ocorre que a grande maioria das traduções assinadas por Britto, incluindo as que ele mesmo discute em seu livro, é de obras associadas à alta literatura, voltadas para a elaboração estética, escritas por autores prestigiados pela crítica acadêmica (como Thomas Pynchon, Don Delillo, Philip Roth, entre outros), e geralmente não alinhadas às temáticas e tramas dos best-sellers que atraem os interesses comerciais mais imediatos da indústria do entretenimento (como, por exemplo, nos best-sellers escritos por John Grisham ou Danielle Steel). Assim, a pergunta que norteou esta pesquisa é se seria possível observar algum contraste relevante, no que diz respeito à ocorrência de marcas de oralidade, entre romances comumente associados à alta literatura e aqueles oriundos do mercado literário de entretenimento. Vejamos do que se trata essa diferença.

\section{Alta literatura e literatura de entretenimento: Indignação, de Philip Roth, e $O$ Manipulador, de John Grisham}

Considera-se que haveria uma diferença, nem sempre absolutamente clara, entre alta literatura e a literatura de entretenimento, representada pelos best-sellers de ficção. Segundo Sodré (1988:5) elas seriam fenômenos diferentes de produção e de reconhecimento literários. Não se deve supor que essa divisão seja estanque, uma vez que uma obra da alta literatura pode ter grande receptividade popular, tornando-se um best-seller, e um livro de literatura de massa pode ser consumido por leitores de alta literatura. Contudo, geralmente, para que uma obra seja considerada como pertencente à alta literatura, ela deve ser reconhecida como tal com base em certas 
balizas institucionais, como, por exemplo, na recepção crítica de determinadas obras (seja no âmbito das universidades ou pela própria crítica escrita em jornais e em revistas especializadas ou mesmo com a concessão de prêmios literários). A literatura de massa ou de entretenimento não desfruta de um suporte como esse, o que não impede, porém, que obras associadas à literatura de entretenimento (como a saga Harry Potter) sejam utilizadas como paradidáticos em escolas, e mesmo que sejam objetos de estudo na universidade. De modo geral, as diferenças nas regras de produção e consumo fazem com que cada uma dessas produções proporcione expectativas diferentes. Não é mera casualidade o fato de que são os best-sellers de entretenimento, e não as obras da alta literatura, que frequentemente ocupam as estantes mais visíveis na entrada das livrarias.

Muniz Sodré (1988) destaca vários aspectos peculiares às obras literárias de entretenimento, como a busca pela linguagem acessível e facilitada, além de certo pedagogismo. Em contraste, obras da chamada alta literatura representam uma intervenção particular na linguagem romanesca e que, com frequência, é imprevisível, pois pode frustrar o leitor que busca, por exemplo, histórias emocionantes, ou de suspense, ou que apresentem um desejado clímax, por vezes traduzido por um "final feliz" e que possam oferecer uma moral de vida a ser seguida (aspectos amplamente explorados na literatura de entretenimento).

Para a presente pesquisa, buscou-se analisar os diálogos em um romance da alta literatura: Indignation/Indignação (2008/2009), de Philip Roth, traduzida por Jorio Dauster, e publicada pela Editora Companhia das Letras; e em um best-seller de ficção: The Racketeer/O manipulador, de John Grisham (2012/2013), traduzido por Maira Parula, e publicado pela editora Rocco.

Philip Roth é um renomado romancista norte-americano de origem judaica, nascido em 1933. Suas narrativas giram em torno do mal-estar da civilização e da hipocrisia social. É o único escritor norte-americano vivo a ter sua obra publicada em edição completa pela Library of America e já escreveu mais de vinte e nove livros, dentre os quais cinco foram adaptados para filmes. Roth também ganhou muitos prêmios, dentre eles o Pulitzer e o Man 
Booker Prize, além da Gold Medal in Fiction, a mais alta distinção da American Academy of Arts and Letters.

$\mathrm{Na}$ obra Indignação, Marcus Messner narra a própria história, que se passa nos Estados Unidos nos anos 1950. Marcus, nascido e criado em Newark, Nova Jersey, é um adolescente ambicioso de dezoito anos, filho único de família judia, que se sente sufocado pela superproteção e intensa desconfiança do pai, e por essa razão decide mudar de cidade e dar continuidade a seus estudos em uma cidade bem distante de casa, evitando contato com o pai e se livrando do trabalho pesado no açougue da família. $\mathrm{Na}$ nova faculdade, recusa uma vida social universitária, centrando-se nos estudos e obtendo sempre notas elevadas, para evitar ser convocado para a Guerra da Coreia. Marcus tem um gênio difícil, e um comportamento às vezes agressivo, tomando várias decisões equivocadas que acabam por determinar seu futuro.

John Grisham, por outro lado, é um dos escritores mais bem sucedidos no campo da literatura de entretenimento: com mais de 30 romances publicados, o autor já vendeu 250 milhões de exemplares em todo o mundo. ${ }^{7}$ Romances como The Firm/A Firma, The Pelican brief/Dossiê Pelicano e The Runaway Jury/O Júri, entre outros, se tornaram produções cinematográficas ou televisivas bem populares. 0 autor se especializou em contar histórias de suspense envolvendo temas policiais e da advocacia, com foco nos tribunais e nas grandes firmas de direito estadunidenses. O Manipulador é um thriller policial que conta a história de Malcolm Bannister, um advogado negro, oriundo de um gueto, e um dos poucos de seu círculo de origem a chegar ao ensino superior, condenado injustamente por crime de colarinho branco.

\section{Marcas de oralidade em $O$ Manipulador e em Indignação: semelhanças e contrastes}

\footnotetext{
7 Segundo informação de um blog dedicado ao autor no Brasil: http://jgrishambrasil.blogspot.com.br
} 
Obviamente, quando se trata de variação linguística em texto traduzido, deve-se considerar que essa variação poderá estar associada, mais diretamente, a situações contextuais de fala entre personagens em que o tradutor observe (ou deixe de observar), por exemplo, maior ou menor intimidade, maior ou menor (as)simetria, e até a maior ou menor diferença de idade entre interlocutores. Além disso, pode-se esperar, também, que a posição social do personagem possa influenciar seu discurso. Vejamos duas passagens das duas obras em análise. Na fala abaixo, em The Racketter/O Manipulador, o personagem Quinn, um traficante presidiário, é pressionado por agentes do FBI, perante os quais reage, com revolta, em vista das acusações feitas por eles:

\begin{tabular}{|c|c|}
\hline The Rackteer & O Manipulador \\
\hline $\begin{array}{l}\text { - And chalk up another lie. My lawyer } \\
\text { will get to the bottom of this. He'll nail } \\
\text { your ass in court, expose you, expose } \\
\text { all your lies. Show me the boot print } \\
\text { analysis. Now, I want to see it. } \\
\text { (GRISHAM, 2012:128, destaques } \\
\text { acrescidos). }\end{array}$ & $\begin{array}{l}\text { - Assinale aí uma outra mentira. Meu } \\
\text { advogado vai chegar fundo nessa } \\
\text { história. Ele vai desmascará-los no } \\
\text { tribunal, expor vocês, expor todas as } \\
\text { suas mentiras. Me mostrem a análise da } \\
\text { pegada da bota. Agora eu quero ver. } \\
\text { (GRISHAM, 2013:122, destaques } \\
\text { acrescidos). }\end{array}$ \\
\hline
\end{tabular}

A comparação entre original e tradução confirma o que Britto (2012) afirma acerca da distância aparentemente menor entre o registro falado e o escrito em inglês, em comparação ao modo como essa distância tende a ser estabelecida pela influência da tradição normativa da língua portuguesa. A fala escrita em inglês é bem próxima ao que, normalmente, poderia ser ouvido na fala de um presidiário que, revoltado, se defende diante dos agentes do FBI. O emprego de “chalk up" e "nail your ass" acentuam a informalidade do discurso do presidiário, marcado pelo desejo de desafiar os agentes. Quando se observa a tradução, nota-se justamente o contrário, ou seja, uma distância maior entre o registro escrito e o registro que poderia ser efetivamente falado, ${ }^{8}$ diminuindo, assim, o grau de verossimilhança em

\footnotetext{
${ }^{8}$ Levando em consideração, é claro, as características próprias da escrita e da fala que, embora não devam ser opostas de forma dicotômica, como bem demonstra Marcuschi (2001), acabam por se organizar de acordo com princípios diferentes, o que certamente impede que se reproduzam todas as especificidades do discurso oral no texto escrito, especialmente
} 
relação a um contexto situacional semelhante: a) o verbo "assinalar" sugere um registro mais formal e menos irônico que "chalk up", o que se intensifica com a forma imperativa do subjuntivo; b) a tradução de "nail your ass" por “desmascarar” tornou o seu discurso mais formal; c) além disso, o uso de pronome obliquo “-los”, em “desmascará-los”, ao atender estritamente a norma padrão, torna o discurso do presidiário mais formal e até respeitoso. Pode-se observar, por outro lado, alguns recursos, na tradução, que são um pouco mais próximos da oralidade, como, por exemplo, o emprego do pronome "vocês" na função de objeto verbal "expor vocês" (em vez de “expô-los”, segundo a norma padrão), e o emprego de construção verbal com objeto anafórico nulo (em “Agora quero ver $\emptyset$ ” em vez “Agora quero vê-la”").

Observemos, agora, a seguinte fala do pai do protagonista Marcus Messner, em Indignação, em que aquele imita, para o filho, o que as clientes diziam quando queriam comprar uma galinha no açougue: "Turn it over. No, over. Let me see the bottom." (ROTH, 2008:5). Essa fala foi traduzida como “Vira ela. Não, pro outro lado. Deixa eu ver a parte de trás” (Roth, 2009:14). Ao optar por “ela”, pronome sujeito, em função de clítico acusativo, o que é absolutamente desabonado pela tradição gramatical conservadora associada à norma padrão, e pelo registro mais informal do verbo "virar" (com o imperativo no modo indicativo - "vira", em vez de “vire”) e pela forma reduzida "pro" (em vez de "para o"), o tradutor produziu uma fala que, na escrita, e à semelhança do trecho no texto original, é mais verossímil e próxima daquilo que se esperaria da fala de um pai imitando, em português, uma cliente em seu açougue.

Nota-se que, em The Racketeer, o contexto situacional prisional e, particularmente, o próprio perfil do personagem, um presidiário traficante de drogas, sob a pressão de várias horas de interrogatório de natureza acusativa, e o próprio emprego de expressões claramente coloquiais em sua fala não foram, ao que parece, fatores suficientes para que, na tradução, houvesse o emprego mais substancial (e até mais consistente) de marcas de oralidade.

diante dos limites que se convencionam aplicar às obras literárias publicadas tradicionalmente. Nesse caso, a verossimilhança que as marcas de oralidade emprestam aos diálogos escritos seria apenas uma imitação, tanto mais próxima quanto é possível, da realidade falada. 
Isso sugere a possibilidade da existência de fatores coercitivos, aparentemente não gerados pelo contexto situacional que circunscreve o diálogo no romance, que poderiam estar condicionando o emprego de formas linguísticas mais alinhadas à norma padrão quando o contexto situacional do diálogo permitiria efetivamente a aplicação mais consistente de marcas de oralidade na tradução.

Se os exemplos extraídos das duas traduções sugerem que, na esteira do que discute Bagno (2012), o hibridismo de normas linguísticas pode ser um aspecto muito mais frequente do que se imagina em traduções, resta avaliar em que medida esse hibridismo é quantitativamente variável, com certas marcas de oralidade, em diálogos, se destacando mais que outras ou, ainda, com formas abonadas pela tradição gramatical conservadora revelando-se mais proeminentes que suas variantes linguísticas prescritas por essa mesma tradição. Para lidar com essa questão, recorreu-se ao escaneamento dos romances, com a seleção somente dos trechos contendo diálogos para a análise quantitativa das marcas de oralidade mais significativas por meio do software gratuito AntConc. ${ }^{9}$ Foram pesquisadas algumas marcas de oralidade fonéticas, morfossintáticas e lexicais (não relacionadas a gírias ou coloquialismos), em contraste com as formas linguísticas correspondentes consideradas como padrão pela tradição gramatical conservadora. Ressalta-se que, nos textos de partida, não há a presença de variedades linguísticas que seriam tipicamente estigmatizadas ou que se associem, destacadamente, a socioletos particulares ou a dialetos regionais, o que também não se verificou nos textos traduzidos.

\subsection{Marcas de oralidade fonéticas}

Vejamos, a seguir, os dados coletados quanto às marcas de oralidade fonéticas:

Tabela 1

\begin{tabular}{|l|c|c|c|c|}
\hline & \multicolumn{2}{|c|}{ O Manipulador } & \multicolumn{2}{c|}{ Indignação } \\
\hline Marcas de & Número de & Percentual & Número de & Percentual \\
\hline
\end{tabular}

${ }_{9}^{9}$ Disponível em: http://www.laurenceanthony.net/software/antconc/ 


\begin{tabular}{|c|c|c|c|c|}
\hline $\begin{array}{c}\text { oralidade } \\
\text { vs. formas } \\
\text { padrão }\end{array}$ & ocorrências & & ocorrências & \\
\hline “pra" & 20 & $5.7 \%$ & 01 & $0.5 \%$ \\
\hline "pro" & 0 & $0.0 \%$ & 01 & $0.5 \%$ \\
\hline "para" & 331 & $94.3 \%$ & 201 & $99 \%$ \\
\hline & & & & \\
\hline "tá" & 17 & $7.4 \%$ & 01 & $0.9 \%$ \\
\hline "está" & 212 & $92.6 \%$ & 107 & $99.1 \%$ \\
\hline & & & & \\
\hline "tô" & 01 & $1.2 \%$ & 0 & $0.0 \%$ \\
\hline “estou" & 86 & $98.8 \%$ & 36 & $100 \%$ \\
\hline & & & & \\
\hline “né?" & 01 & $7.2 \%$ & 0 & $0.0 \%$ \\
\hline "não é?" & 13 & $92.8 \%$ & 03 & $100 \%$ \\
\hline
\end{tabular}

Embora, em ambos os romances, o emprego das formas consideradas padrão seja muito superior às marcas de oralidade fonéticas correspondentes, a ocorrência destas é percentualmente maior no best-seller 0 Manipulador, com destaque para "tá" e "pra”. Vejamos alguns exemplos extraídos desse romance:

\begin{tabular}{|l|l|}
\hline \multicolumn{1}{|c|}{ The Rackteer } & \multicolumn{1}{c|}{ O Manipulador } \\
\hline $\begin{array}{l}\text { “Look, Nathan, this is all my fault, } \\
\text { okay?” (GRISHAM, 2012:300) }\end{array}$ & $\begin{array}{l}\text { Olha, Nathan, isso tudo é minha culpa, tá } \\
\text { legal? (GRISHAM, 2013:275) }\end{array}$ \\
\hline
\end{tabular}

As ocorrências de "tá" estão majoritariamente associadas à tradução de marcadores discursivos como “okay?", “right?”, ou “you got that?”, [este traduzido por “tá entendendo?” (GRISHAM, 2012:271)], e raramente relacionadas a construções verbais comuns (apenas três ocorrências em todo o romance), como no caso de “O bicho tá pegando (GRISHAM, 2013:123)”, tradução de “this is getting ugly" (GRISHAM, 2012:130). Há apenas 20 ocorrências de "pra” (contra 331 de "para"), algumas das quais em diálogos como o que envolve um traficante de drogas:

\begin{tabular}{|l|l|}
\hline \multicolumn{1}{|c|}{ The Rackteer } & \multicolumn{1}{|c|}{ O Manipulador } \\
\hline “You're not dealing in any way?" & - Não está traficando nada? \\
“Hell no. I'm not going to prison, Reed. & - Não, caramba. Não vou voltar pra \\
\hline
\end{tabular}


A preposição "para”, porém, ocorre em uma outra fala, do mesmo traficante, na qual, pela própria situação contextual, poderia ter sido reduzida para "pra" (como no caso anterior): "Me levaram para a cadeia em Bluefield [...]" (GRISHAM, 2013:241). O emprego bastante parcimonioso das marcas de oralidade fonética pode estar relacionado, como aponta Britto (2012), com a preocupação, por parte do tradutor e da editora, de que o leitor final julgue a ocorrência como sendo não padrão ou um erro de ortografia. É interessante observar que a fala acima é iniciada com o pronome oblíquo "me", o que é tradicionalmente prescrito pela norma padrão. Seria de se esperar que, numa fala como essa, iniciada por "me”, o emprego de "pra" fosse mais consistente que a opção por “para”, o que demonstra que, em 0 Manipulador, o emprego sistemático de várias marcas de oralidade em uma mesma fala tende a ser evitado.

\subsection{Marcas de oralidade morfossintáticas}

\subsubsection{Quatro categorias com ocorrências que não evidenciam contrastes relevantes entre os dois romances}

A seguir, contrastamos os dados obtidos para as marcas de oralidade lexicais e morfossintáticas:

Tabela 2

\begin{tabular}{|l|c|c|c|c|}
\hline & \multicolumn{2}{|c|}{ O Manipulador } & \multicolumn{2}{c|}{ Indignação } \\
\hline $\begin{array}{l}\text { Marcas de } \\
\text { oralidade vs. } \\
\text { formas padrão }\end{array}$ & $\begin{array}{l}\text { Número de } \\
\text { ocorrências }\end{array}$ & Percentual & $\begin{array}{l}\text { Número de } \\
\text { ocorrências }\end{array}$ & Percentual \\
\hline $\begin{array}{l}\text { Isso, Esse(s), } \\
\text { Essa(s) }\end{array}$ & 334 & $90.5 \%$ & 186 & $93 \%$ \\
\hline
\end{tabular}




\begin{tabular}{|c|c|c|c|c|}
\hline $\begin{array}{l}\text { Isto, Este(s), } \\
\text { Esta(s) }\end{array}$ & 35 & $9.5 \%$ & 14 & $7 \%$ \\
\hline $\begin{array}{l}\text { (Uso “não } \\
\text { canônico" de } \\
\text { preposição) } \\
\text { Ir em (o/a) } \\
\text { Ex.: "Fui na } \\
\text { delegacia”" }\end{array}$ & 0 & $0.0 \%$ & 0 & $0.0 \%$ \\
\hline $\begin{array}{l}\text { (Uso "canônico" } \\
\text { de preposição) } \\
\text { Ir a (o) } \\
\text { Ex.: "Fui à } \\
\text { delegacia" }\end{array}$ & 12 & $100 \%$ & 0 & $0.0 \%$ \\
\hline $\begin{array}{l}\text { Presença } \\
\text { redundante do } \\
\text { pronome sujeito } \\
\text { “eu” seguido de } \\
\text { verbo com } \\
\text { terminação “-ei” } \\
\text { Ex.: “Eu falei com } \\
\text { ele" }\end{array}$ & 28 & $15.2 \%$ & 9 & $10.6 \%$ \\
\hline $\begin{array}{l}\text { Omissão do } \\
\text { pronome sujeito } \\
\text { "eu" em verbos } \\
\text { com terminação } \\
\text { “-ei” } \\
\text { Ex.: "Falei com } \\
\text { ele" }\end{array}$ & 157 & $84.8 \%$ & 76 & $89.4 \%$ \\
\hline $\begin{array}{l}\text { Emprego do } \\
\text { pronome “me" } \\
\text { em posição } \\
\text { proclítica (não } \\
\text { iniciando a } \\
\text { oração) }\end{array}$ & 188 & $88.6 \%$ & 115 & $87.1 \%$ \\
\hline $\begin{array}{l}\text { Emprego do } \\
\text { pronome "Me" } \\
\text { em posição } \\
\text { proclítica } \\
\text { iniciando a oração }\end{array}$ & 13 & $6.2 \%$ & 12 & $9.1 \%$ \\
\hline $\begin{array}{l}\text { Emprego do } \\
\text { pronome “me" } \\
\text { em posição } \\
\text { enclítica }\end{array}$ & 11 & $5.2 \%$ & 5 & $3.8 \%$ \\
\hline
\end{tabular}


Em ambos os romances, a ocorrência dos pronomes demonstrativos "isso, esse(s), essa(s)" é bem superior ao emprego dos que se associam tradicionalmente à norma padrão, no caso "isto, este(s), esta(s)". Essa diferença reflete justamente o uso muito mais amplo dos primeiros na fala dos brasileiros, já que o encontro consonantal "-st-" sofre, na prática comunicativa, um processo de assimilação, com o seu desaparecimento (cf. BAGNO, 2009:167). Outro aspecto que reflete a influência da fala vernácula (que favorece naturalmente a próclise) na escrita é o emprego dos pronomes oblíquos em posição proclítica, ou seja, antes do verbo, como é o caso de "me". A pesquisa revelou que as ocorrências de "me" em posição proclítica [Ex.: "Ele me chamou para me interrogar..." (Roth, 2009:97)] são muito maiores quando comparadas ao emprego do mesmo pronome em posição enclítica [Ex.: "Bem, diga-me agora,..." (Roth, 2009:81)]. Até o uso do pronome oblíquo "me" iniciando a oração, algo que geralmente é proscrito pela maioria dos compêndios gramaticais, é ligeiramente maior, em $O$ Manipulador, e sensivelmente maior, em Indignação, que o emprego do pronome enclítico. Por outro lado, não se observou, em nenhum dos romances o emprego não canônico de preposições, como no caso de "ir na delegacia" (incluindo também formas conjugadas), muito mais próximo da oralidade, em vez de "ir à delegacia" (regência canônica). Ressalta-se, porém, que a não ocorrência, em Indignação, dessas formas linguísticas, nem canônicas nem desabonadas, simplesmente reflete a ausência de construções linguísticas que, em inglês, poderiam ter levado o tradutor a produzir formas com estruturas semelhantes (canônicas ou não) em português. Outro aspecto é a explicitação do pronome sujeito redundante, uma tendência do português brasileiro falado. Sua frequência, porém, foi menor em ambos os romances, em comparação às ocorrências verbais com sujeitos nulos. 0 que poderia explicar isso é, talvez, a necessidade do tradutor em tornar o texto estilisticamente mais coeso, com menos repetições do pronome sujeito, como se pode notar na tradução abaixo, em que a explicitação do pronome "eu" ocorre apenas uma única vez (quando no original, em inglês, é repetido obrigatoriamente três vezes): 


\begin{tabular}{|c|c|}
\hline Indignation & Indignação \\
\hline $\begin{array}{l}\text { “[...] exactly what is the crime l've } \\
\text { committed? So l've moved a couple of } \\
\text { times, l've moved from one dorm room } \\
\text { to another [...] ( ROTH,2008:96) }\end{array}$ & $\begin{array}{l}\text { “[...] qual é exatamente o crime que eu } \\
\text { cometi? De fato [Ø] me mudei duas } \\
\text { vezes, [Ø] me mudei de um quarto de } \\
\text { dormitório para outro [...] } \\
\text { (RoTH, } \\
2009: 76)\end{array}$ \\
\hline
\end{tabular}

\subsubsection{Dez categorias com ocorrências que evidenciam contrastes relevantes entre os dois romances:}

Visualizaremos agora dez categorias que exibem contrastes importantes entre os dois romances.

\section{Tabela 3}

\begin{tabular}{|l|c|c|c|c|}
\hline & \multicolumn{2}{|c|}{ O Manipulador } & \multicolumn{2}{c|}{ Indignação } \\
\hline $\begin{array}{l}\text { Marcas de } \\
\text { oralidade vs. } \\
\text { formas padrão }\end{array}$ & $\begin{array}{l}\text { Número de } \\
\text { ocorrências }\end{array}$ & Percentual & $\begin{array}{l}\text { Número de } \\
\text { ocorrências }\end{array}$ & Percentual \\
\hline $\begin{array}{l}\text { "Ele(s)/ela(s)" } \\
\text { com função de } \\
\text { objeto verbal }\end{array}$ & 0 & $0.0 \%$ & 5 & $20.9 \%$ \\
$\begin{array}{l}\text { Ex.: “Encontrei } \\
\text { ele na avenida” }\end{array}$ & 50 & $100 \%$ & 19 & $79.16 \%$ \\
\hline $\begin{array}{l}\text { “O(s)/a(s)" em } \\
\text { posição proclítica }\end{array}$ & & & & \\
$\begin{array}{l}\text { Ex.: “Eu o } \\
\text { encontrei na } \\
\text { avenida” }\end{array}$ & $0.0 \%$ & 15 & $75 \%$ \\
\hline $\begin{array}{l}\text { Ele(s)/ela(s) com } \\
\text { função de objeto } \\
\text { verbal e de } \\
\text { sujeito de oração } \\
\text { encaixada (no } \\
\text { infinitivo) }\end{array}$ & 0 & & & \\
$\begin{array}{l}\text { Ex.: “Deixa ele } \\
\text { cantar” }\end{array}$ & 0 & & & \\
\hline
\end{tabular}




\begin{tabular}{|c|c|c|c|c|}
\hline $\begin{array}{l}\text { O(s)/a(s)/-lo(s)/- } \\
\text { la(s) seguido de } \\
\text { oração encaixada } \\
\text { (no infinitivo) } \\
\text { Ex.: “Deixe-o } \\
\text { cantar” }\end{array}$ & 4 & $100 \%$ & 5 & $25 \%$ \\
\hline $\begin{array}{l}\text { Mescla entre } \\
\text { pronome "você" } \\
\text { e pronome } \\
\text { oblíquo "te" } \\
\text { Ex.: "Você sabe } \\
\text { que eu te amo" }\end{array}$ & 3 & $11.5 \%$ & 32 & $100 \%$ \\
\hline $\begin{array}{l}\text { Correspondência } \\
\text { canônica entre } \\
\text { pronome "você" } \\
\text { e pronomes } \\
\text { oblíquos "o", "a" } \\
\text { Ex.: "Você sabe } \\
\text { que eu a amo" }\end{array}$ & 23 & $88.5 \%$ & 0 & $0.0 \%$ \\
\hline $\begin{array}{l}\text { Regência nominal } \\
\text { NÃO CANÔNICA } \\
\text { Substantivo/ } \\
\text { Particípio + que } \\
\text { (substituindo de } \\
\text { que/a que) } \\
\text { Ex.: "Tinha } \\
\text { certeza que era } \\
\text { verdade" }\end{array}$ & 0 & $0.0 \%$ & 7 & $33.4 \%$ \\
\hline $\begin{array}{l}\text { Regência nominal } \\
\text { CANÔNICA } \\
\text { Substantivo/ } \\
\text { particípio + de } \\
\text { que / a que } \\
\text { Ex.: "Tinha } \\
\text { certeza de que } \\
\text { era verdade" }\end{array}$ & 63 & $100 \%$ & 14 & $66.6 \%$ \\
\hline $\begin{array}{l}\text { (0) que que....? I } \\
\text { (0) que é que...? }\end{array}$ & 0 & $0.0 \%$ & 9 & $32.2 \%$ \\
\hline O que...? & 45 & $100 \%$ & 19 & $67.8 \%$ \\
\hline $\begin{array}{l}\text { Ter que (e formas } \\
\text { conjugadas) }\end{array}$ & 0 & $0.0 \%$ & 3 & $21.5 \%$ \\
\hline $\begin{array}{l}\text { Ter de (e formas } \\
\text { conjugadas) }\end{array}$ & 26 & $100 \%$ & 11 & $78.57 \%$ \\
\hline
\end{tabular}




\begin{tabular}{|c|c|c|c|c|}
\hline $\begin{array}{l}\text { Imperativo } \\
\text { (no modo }^{10} \\
\text { indicativo) }\end{array}$ & $\begin{array}{l}\text { Deixa: } 1 \\
\text { Diz: } 0 \\
\text { Faz: } 0 \\
\text { Pensa: } 0 \\
\text { Toma: } 0 \\
\text { Total: } 01\end{array}$ & $3.1 \%$ & $\begin{array}{l}\text { Deixa: } 6 \\
\text { Diz: } 1 \\
\text { Faz: } 0 \\
\text { Pensa: } 1 \\
\text { Toma: } 3 \\
\text { Total: } 11\end{array}$ & $38 \%$ \\
\hline $\begin{array}{l}\text { Imperativo } \\
\text { (no modo } \\
\text { subjuntivo) }\end{array}$ & $\begin{array}{l}\text { Deixe: } 6 \\
\text { Diga: } 12 \\
\text { Faça: } 9 \\
\text { Pense: } 5 \\
\text { Tome: } 0 \\
\text { Total: } 32 \\
\end{array}$ & $96.9 \%$ & $\begin{array}{l}\text { Deixe: } 6 \\
\text { Diga: } 4 \\
\text { Faça: } 5 \\
\text { Pense: } 2 \\
\text { Tome: } 1 \\
\text { Total: } 18 \\
\end{array}$ & $62 \%$ \\
\hline Tinha + particípio & 7 & $87.5 \%$ & 4 & $44.5 \%$ \\
\hline Havia + particípio & 1 & $12.5 \%$ & 5 & $55.5 \%$ \\
\hline $\begin{array}{l}\text { "Tem" } \\
\text { (impessoal) }\end{array}$ & 28 & $40 \%$ & 3 & $12 \%$ \\
\hline "Há" (impessoal) & 42 & $60 \%$ & 22 & $88 \%$ \\
\hline $\begin{array}{l}\text { Artigo definido } \\
\text { diante de nome } \\
\text { próprio }^{11}\end{array}$ & $\begin{array}{c}\text { O } \text { Bannister } \\
\text { O Gene } \\
7 \\
7\end{array}$ & $6.9 \%$ & $\begin{array}{r}\text { O Eddie } \\
\text { A Olivia } \\
\\
11\end{array}$ & $44 \%$ \\
\hline $\begin{array}{l}\text { Nome próprio não } \\
\text { precedido por } \\
\text { artigo definido }\end{array}$ & $\begin{array}{c}\varnothing \text { Bannister } \\
\varnothing \text { Gene } \\
95\end{array}$ & $93.1 \%$ & $\begin{array}{r}\emptyset \text { Eddie } \\
\varnothing \text { Olivia } \\
14\end{array}$ & $56 \%$ \\
\hline
\end{tabular}

Ao observarmos todas as tabelas anteriores, notamos basicamente as seguintes informações gerais:

\section{Tabela 4}

\footnotetext{
${ }^{10}$ Uma vez que seria inviável fazer uma pesquisa com todos os possíveis verbos utilizados no imperativo, selecionaram-se apenas verbos recorrentes em ambas as narrativas. Para que a pesquisa pudesse oferecer um parâmetro de comparação, utilizaram-se os mesmos verbos nos dois modos diferentes do imperativo, sendo que o do Indicativo é o mais próximo da oralidade.

11 Nesse caso, foram selecionados, para a pesquisa, apenas dois personagens de cada romance, cujos nomes, no enredo, além de serem recorrentes, também são mencionados por outros personagens com frequência.
} 


\begin{tabular}{|c|c|c|}
\hline Informações gerais & O Manipulador & Indignação \\
\hline $\begin{array}{l}\text { Número de categorias } \\
\text { em que o percentual de } \\
\text { ocorrências associadas à } \\
\text { norma padrão é maior } \\
\text { (em comparação à } \\
\text { variedade oral) }\end{array}$ & 15 & 13 \\
\hline $\begin{array}{l}\text { Número de categorias } \\
\text { em que o percentual de } \\
\text { ocorrências associadas } \\
\text { às marcas de oralidade } \\
\text { é maior (em } \\
\text { comparação à norma } \\
\text { padrão) }\end{array}$ & 4 & 5 \\
\hline $\begin{array}{l}\text { Número de categorias } \\
\text { com nenhuma } \\
\text { ocorrência de marcas de } \\
\text { oralidade. }\end{array}$ & 7 & 3 \\
\hline $\begin{array}{l}\text { Número de categorias } \\
\text { com nenhuma } \\
\text { ocorrência de formas } \\
\text { associadas à norma } \\
\text { padrão. }\end{array}$ & 0 & 2 \\
\hline $\begin{array}{l}\text { Número de categorias } \\
\text { com percentual de } \\
\text { ocorrência de marcas de } \\
\text { oralidade SUPERIOR A } \\
0 \%\end{array}$ & 13 & 17 \\
\hline $\begin{array}{l}\text { Marcas de oralidade que } \\
\text { se destacam com maior } \\
\text { número de ocorrências } \\
\text { (comparando-se um livro } \\
\text { com o outro) }\end{array}$ & $\begin{array}{c}\text { 1. "pra”* } \\
\text { 2. "tá" * } \\
\text { 3. "tô" } \\
\text { 4."né" } \\
\text { 5. "isso/esse/essa" * }\end{array}$ & $\begin{array}{c}\text { 1. "pro" } \\
\text { 2. "ele/ela (objeto } \\
\text { verbal”) } \\
\text { 3. “ele/ela (objeto } \\
\text { verbal e sujeito da frase }\end{array}$ \\
\hline
\end{tabular}




\begin{tabular}{|c|c|c|}
\hline $\begin{array}{l}\text { Obs.: O asterisco diante } \\
\text { da marca de oralidade } \\
\text { indica que ela ocorre } \\
\text { nos dois livros (embora } \\
\text { em quantidades } \\
\text { diferentes). }\end{array}$ & $\begin{array}{l}\text { 6. “eu”* } \\
\text { 7. “me ("proclítico") * } \\
\text { 8. “Me" (proclítico } \\
\text { iniciando frase”) * } \\
\text { 9. Ter (como haver) * } \\
\text { 10. "tinha + particípio" * }\end{array}$ & $\begin{array}{c}\text { seguinte) } \\
\text { 4. “você + te" * } \\
\text { 5. “queísmo" } \\
\text { 6. “o que (é) que” } \\
\text { 7. “ter que" } \\
\text { 8. “Imperativo } \\
\text { indicativo" * } \\
\text { 9. “Artigo + nome } \\
\text { próprio" * }\end{array}$ \\
\hline
\end{tabular}

Observa-se que, na construção dos diálogos, a norma padrão é seguida majoritariamente em ambos os romances. No entanto, percebe-se uma diferença notável quanto à presença mais sistemática de variedades linguísticas associadas à oralidade no romance Indignação. Nesse romance, o leque de variedades linguísticas orais é maior em comparação aos dados referentes ao romance $O$ Manipulador. Além disso, alguns dados chamam bastante a atenção, como, por exemplo, a ocorrência de pronome lexical "ele/ela" na função de objeto verbal, como em "Não leva ele a sério" (Roth, 2009:27), em vez de "Não o leve a sério", ou, quando, além de funcionar como objeto de um verbo, também atua como sujeito de oração encaixada, como em "[...] Markie, eu ouvi ele dizer ao senhor Pearlgreen [...]" (Roth, 2009:19). Luchesi (2015) faz uma afirmação relevante, baseada em resultados de pesquisas sociolinguísticas, em relação à avaliação que os falantes tendem a fazer dessas três estruturas: a) clítico acusativo de $3^{\text {a }}$ pessoa ("o", "os", "a", "as"); b) os pronomes lexicais "ele(s)/ela(s)" exercendo a função de objeto verbal (estrutura simples); e c) os pronomes lexicais "ele(s)/ela(s)" exercendo a função de objeto verbal e de sujeito de oração encaixada (estrutura complexa).

[...] o uso do clítico em certas estruturas, particularmente em tempos compostos (e.g, "não a tenho visto ultimamente"), na oralidade, pode ser avaliado negativamente, como pedante. Por outro lado, em relação ao pronome lexical, o seu emprego em estruturas simples é aceito como próprio da fala informal, mas os falantes exibem consciência de que é um uso desviante da norma gramatical e que seria impróprio na escrita, ou mesmo 
em situações mais formais. Porém, em estruturas mais complexas, em que o pronome funciona também como sujeito de uma predicação encaixada, o uso dessa variante é bem-aceito, ou melhor, passa despercebido. Bagno (2001), inclusive, recolhe uma série de exemplos desse tipo em textos escritos por jornalistas. (LUCHESI, 2015: 232-3)

Essas variedades orais, de que fala Luchesi (2015), não aparecem uma única vez nos diálogos de 0 Manipulador, ${ }^{12}$ mas várias vezes em Indignação, incluindo estruturas linguísticas simples - como "Não leve ele a sério" - que tenderiam, como salienta Luchesi, a serem percebidas como sendo até mais "impróprias", em situações formais ou na escrita, do que as estruturas encaixadas (ou “complexas"). Além dessas estruturas, observa-se também que, em Indignação, não há uma única ocorrência canônica envolvendo a combinação entre o sistema pronominal que inclui "você" e o sistema de pronomes objeto, como "o", "a" e "lhe”, ou seja, nesse romance só ocorre a mistura de "você" com "te", o que é tradicionalmente prescrito por grande parte dos compêndios gramaticais. No caso de $O$ Manipulador, observa-se apenas uma única categoria que, de maneira mais evidente que as outras, por ser associada à modalidade oral da língua, tende a ser avaliada negativamente quando de sua ocorrência na escrita: o emprego do verbo "ter" no sentido impessoal de "haver". Embora ocorram percentualmente menos (40\%) que a forma padrão ("há" - 60\%), as construções com "tem" [como em "O que tem dentro?" (GRISHAM, 2013:311)], são percentualmente mais frequentes quando comparadas às ocorrências semelhantes em Indignação (12\%). Em resumo, em o Manipulador, as únicas categorias que poderiam, talvez, atrair algum julgamento negativo de leitores mais informados pela tradição gramatical conservadora, seriam o emprego do pronome oblíquo "me" em início de oração, e o uso do verbo ter com sentido impessoal de "haver". Marcas de oralidade como "mescla de você e te", "queísmo", "imperativo indicativo" e "artigo + nome próprio", além dos já citados acima, são menos recorrentes, ou até evitadas, em $O$ Manipulador, enquanto se fazem presentes com maior frequência em Indignação, de modo que se pode chegar à conclusão de que, em Indignação, o tradutor parece ter "se arriscado" mais ao empregar formas

\footnotetext{
${ }^{12}$ Embora haja várias passagens, no texto em inglês, que suscitariam esse tipo de construção em português.
} 
linguísticas que, embora não sejam, de fato, estigmatizadas nas práticas orais, ainda podem atrair alguma forma de censura no plano da escrita.

\section{Considerações finais}

A pesquisa demonstrou que no romance Indignação houve uma ocorrência mais significativa de marcas de oralidade, incluindo formas que poderiam suscitar algum julgamento negativo por parte do leitor (especialmente aquele que seria atento a certas prescrições da tradição normativa). Embora não tenha excluído determinadas marcas de oralidade, $O$ Manipulador apresentou percentuais mais moderados, e em certos casos inexistentes, em relação a várias marcas de oralidade. Não se pode, porém, estabelecer uma relação necessária e inequívoca entre alta literatura e a ocorrência de marcas de oralidade. Em primeiro lugar porque apenas um romance de alta literatura foi aqui analisado. Em segundo lugar, há traduções da alta literatura que não apresentam marcas de oralidade sistemáticas ou mesmo formas linguísticas consideradas estigmatizadas. Uma variedade linguística dialetal do norte da Inglaterra, presente em diálogos do clássico Wuthering Heights, de Emily Brontë, desaparece em várias traduções brasileiras para dar lugar à norma padrão (cf. CARVALHO, 2006). Além disso, não se deve ignorar o fato de que sob o rótulo de alta literatura (da língua inglesa, no caso), há obras com características tão diferentes: desde os "clássicos" de Shakespeare, Brontë, Poe, entre outros, às obras de autores modernos e contemporâneos, como Virginia Woolf, Don Delillo, Phillip Roth, ou lan McEwan. Clássicos escritos no século XIX, como Wuthering Heights, ou em séculos anteriores, podem suscitar a percepção de que o distanciamento temporal em relação à atualidade exigiria até certo ponto a recriação de uma linguagem, na tradução, que refletisse minimamente esse distanciamento, com um registro talvez mais formal ou mais alinhado à norma padrão na tradução de diálogos. Isso poderia criar um contexto menos favorável à inclusão sistemática de marcas de oralidade que representem a variação de 
natureza diafásica. Esse distanciamento temporal poderia não ser, portanto, um fator coercitivo que limitaria o emprego de marcas de oralidade na tradução de obras contemporâneas às quais é atribuído o rótulo de alta literatura.

No caso de Indignação, não parece ter ocorrido um pré-julgamento que tivesse limitado consideravelmente a ocorrência de marcas de oralidade muito possivelmente porque elas refletem, com maior proximidade, os usos reais da língua falada até mesmo por pessoas letradas. Contudo, para chegarmos a essa conclusão, temos que supor que a editora e o tradutor teriam construído uma imagem ideal do leitor de Indignação: alguém que fosse suficientemente aberto à ideia de variação linguística, e menos propenso ao tipo de crítica norteada pelo discurso do "certo versus errado", associado à tradição gramatical conservadora.

Numa direção aparentemente diferente, uma obra difundida como best-seller, como é o caso de 0 Manipulador, poderia, em princípio, estar mais limitada por interesses comerciais mais imediatos. Se os best-sellers tendem a primar pela legibilidade acessível e pela fluidez na leitura - o que potencializaria as vendas - as marcas de oralidade até poderiam contribuir para isso, já que, ao serem mais próximas da realidade falada, tornariam os diálogos mais "prováveis" e menos artificiais. Não se pode, porém, desprezar o fato de que a variação linguística não é concebida no senso comum como uma possibilidade legítima de expressão tal como reconhecido pela linguística contemporânea e pela sociolinguística. Essas disciplinas são pouco conhecidas e difundidas entre a maioria dos leitores, que passou grande parte da sua formação educativa tendo de se adequar às regras gramaticais tradicionais defendidas nas escolas e nas principais mídias do país, como as únicas balizas aceitáveis para a expressão oral e escrita da língua portuguesa. Acrescenta-se a isso o próprio fato de que obras estrangeiras consideradas best-sellers de entretenimento tendem a ser publicadas, no Brasil, em tiragens maiores, justamente porque pressupõem a possibilidade de sucesso de vendagem já registrada pelo seu autor em seu país de origem. Esse fator torna a publicação desses best-sellers um investimento de risco, especialmente com a inclusão de marcas de oralidade que poderiam levar a uma avaliação negativa dos 
leitores, o que seria um motivo para que, em princípio, certas editoras sejam mais cautelosas quanto à inclusão ampla da variação linguística na tradução de best-sellers, como ficou demonstrado no caso de $O$ Manipulador.

Uma hipótese que precisa ser testada é se, de fato, as obras associadas à alta literatura, por estarem mais diretamente relacionadas à própria experimentação estética e linguística (sem serem guiadas pelo compromisso imediato de vendabilidade máxima), poderiam estar mais propensas à admissão da heterogeneidade linguística, podendo contar, também, com a percepção (imaginada) acerca de seus potenciais leitores, teoricamente menos preocupados com a aceitabilidade ou não de determinadas formas linguísticas, do que com a experiência de leitura que promova alguma forma de renovação, seja no plano estético, temático ou da linguagem (nesse sentido, a variação linguística até poderia contribuir para isso).

De outra parte, resta avaliar, com maior profundidade, em que medida o emprego menos sistemático de formas linguísticas associadas à oralidade, em best-sellers de entretenimento, significaria garantir que a leitura do texto seja menos interrompida com a possibilidade de avaliações negativas do leitor, chamando, assim, menos a sua atenção para a linguagem em que o texto está escrito, do que para o conteúdo e a trama que ele veicula.

São necessárias, enfim, mais pesquisas que avaliem a relação entre tradução de alta literatura, de best-sellers de ficção e a frequência de variantes linguísticas que representem tanto formas dialetais/socioletais particulares à variação sociolinguística diastrática e diatópica, quanto variedades linguísticas que, sendo de natureza diafásica, embora não sejam de fato estigmatizadas nos intercâmbios linguístico orais mais informais, podem sofrer alguma forma de restrição em vista de fatores coercitivos extratextuais que limitariam a (ampla) aplicação do princípio da verossimilhança à construção de diálogos ficcionais. 


\section{Referências bibliográficas}

ANTHONY, L. AntConc 3.5.0. Software. Disponível em: <http://www.laurenceanthony.net/software/antconc/>. Acesso em: jul. 2016.

AZEVEDO, M. Vozes em branco e preto: a representação literária da fala não padrão. São Paulo: Edusp, 2003.

Bagno, M. Português ou brasileiro? Um convite à pesquisa. São Paulo: Parábola Editorial, 2001.

. Não é errado falar assim! Em defesa do português brasileiro. São Paulo: Parábola Editorial, 2009.

- Norma linguística, hibridismo \& tradução. Traduzires, v. 1, n. 1, p.19-32, 2012.

BRITTO, P. H. A tradução literária. Rio de Janeiro: Civilização Brasileira, 2012.

CARVALHO, S. P. A tradução de variantes dialetais no Brasil: uma discussão das ideias de Gillian Lane-Mercier. Estudos Linguísticos, XXXV, p. 18521860, 2006.

Faraco, C. A. Norma culta brasileira: desatando alguns nós. São Paulo: Parábola Editorial, 2009.

GRISHAM, J. The Racketeer. New York: Dell Books, 2012.

- O Manipulador. Tradução de Maira Parula. Rio de Janeiro: Rocco, 2013.

MARCUSCHI, L. A. Da fala para a escrita: atividades de retextualização. São Paulo: Cortez, 2001.

PRETI, D. A representação escrita das variações da língua oral. In.: Sociolinguística: os níveis de fala. 7.ed. São Paulo: Edusp, 1994.

. O discurso oral culto. São Paulo: Humanitas, 1997.

- Diálogo de ficção e realidade linguística. In.: Estudos de língua oral e escrita. Rio de Janeiro: Lucerna, 2004.

SODRÉ, M. Best-seller: a literatura de mercado. 2.ed. São Paulo: Ática, 1988. 
LUCHESI, D. Língua e sociedade partidas: a polarização sociolinguística do Brasil. São Paulo: Contexto, 2015.

Rотн, P. Indignation. Boston, New York: Houghton Mifflin Company, 2008.

- Indignação. Tradução de Jorio Dauster. São Paulo: Companhia das Letras, 2009.

Recebido em: 04/09/2017

Aceito em: 14/09/2018

Publicado em outubro de 2018 